\title{
Tobacco and transition: an overview of industry investments, impact and influence in the former Soviet Union
}

\author{
A B Gilmore, M McKee
}

Tobacco Control 2004;13:136-142. doi: 10.1136/tc.2002.002667

See end of article for authors' affiliations

Correspondence to: Dr A Gilmore, European Centre on Health of Societies in Transition, London School of Hygiene and Tropical Medicine, Keppel Street, London WCIE 7HT, UK; anna. gilmore@lshtm.ac.uk

Received 27 November 2002 Accepted 23 October 2003 Objectives: To quantify the contribution the tobacco industry has made to foreign direct investment (FDI) in
the former Soviet Union (FSU) as an indicator of its political and economic leverage; to explore the impact the former Soviet Union (FSU) as an indicator of its political and economic
this has had on production capacity and tobacco control in the region.

Design: Data on industry investment and its impact on cigarette production capacity were collated from industry journals, reports, and websites. Data on total FDI were obtained from the European Bank of Reconstruction and Development.

Results: By the end of 2000, transnational tobacco companies (TTCs) had invested over US\$2.7 billion in 10 countries of the FSU. Tobacco money as a proportion of FDI varies from $1 \%$ to over $30 \%$ in Uzbekistan. Cigarette production capacity in the factories receiving investments tripled from 146 to 416 billion cigarettes per annum and the TTCs' market share has increased from nothing to between $50-100 \%$ in the markets in which they invested. Findings suggest that the effectiveness of national tobacco control measures corresponds broadly to the nature of the political and economic transition in each country and the size of industry investment, which is determined in part by the political context. Thus more effective measures tend to be seen in democratic states with smaller or no industry investments while the least effective measures are seen in highly centralised, one party states with high levels of industry investment or those with limited governmental capacity.

Conclusions: The entry of the TTCs at a time of major political and economic change left the FSU particularly vulnerable to industry influence. This influence was enhanced by the industry's significant contribution to FDI, their ability to take over existing state monopolies in all but the largest countries, and the lack of democratic opposition.
W hen the Soviet Union collapsed, each of the newly independent states inherited its own government owned tobacco industry. But the centrally funded subsidies for growers and producers had ended and the centralised tobacco import and distribution system broken down, leaving individual factories to fend for themselves. The chaotic state of the industry and the pronounced cigarette shortages seen at the time, ${ }^{1}$ combined with the rejection of Marxist-Leninist ideology and the lurch towards market reform, provided an obvious opportunity for the transnational tobacco companies (TTCs)—one which they were quick to exploit.

Experience elsewhere shows that entry of the TTCs leads to increased competition with or replacement of the local, unsophisticated industry with a powerful corporation with widespread implications for tobacco control. ${ }^{23}$ Western style marketing techniques and new lighter brands that are easier to smoke, including specific brands for women, are introduced. It has also been suggested that state run industries are less likely than TTCs to deny evidence of tobacco's health impacts, challenge public health initiatives, and obstruct national tobacco control laws by exerting political and commercial pressures. ${ }^{2}$ In countries with little experience in dealing with such powerful actors, particularly where large sums of money are involved, the impact may be substantial. This is supported by econometric analyses which show that opening tobacco markets to the TTCs through trade liberalisation leads to significant increases in cigarette consumption..$^{4-6}$

Despite its scale, little has yet been written about the impact of transition and market liberalisation on the tobacco industry in the former Soviet Union (FSU), which along with Central and Eastern Europe has been the main focus for tobacco industry investments over the last decade. This paper updates a 1995 overview of TTC investments in the region. ${ }^{7}$ It examines the contribution the tobacco industry has made to total foreign direct investment (FDI) as an indicator of the industry's economic leverage, and explores the impact TTCs have had on production capacity, brand development, advertising, and tobacco control in each of the former Soviet states. The findings provide an important basis for understanding and interpreting the influence of TTCs on tobacco control in the region.

\section{METHODS}

Details of tobacco industry investments in countries of the FSU from 1990 to the end of 2000 were obtained from tobacco industry websites, company annual reports, tobacco industry journals (Tobacco Journal International and Tobacco Reporter), European Bank of Reconstruction and Development (EBRD) investment reports, and a review of published literature. The same data sources were used to estimate changes in cigarette production capacity by comparing reported capacity before and after investment. For the latter, the most recent data are reported. Where no post-investment capacity data were available, data on actual production were sought and, if missing, it was assumed that the factory continued to produce at pre-investment levels.

Data on total net FDI inflows to the countries receiving significant tobacco investments were obtained directly from the EBRD for the period 1992 (when the first TTC

Abbreviations: BAT, British American Tobacco; EBRD, European Bank of Reconstruction and Development; FDI, foreign direct investment; FSU, former Soviet Union; IMF, International Monetary Fund; TTCs, transnational tobacco companies 
investments occurred) to 2000. Identical data have since been made available on the United Nations Conference on Trade and Development website (http://www.unctad.org/en/ subsites/dite/fdistats_files/fdistats.htm). The proportion of FDI contributed by tobacco industry investments was calculated for each country. Definitions of FDI used were taken from the 2001 World Investment Report where net FDI is defined as credits less debits. ${ }^{8}$

Information on tobacco control was taken from a number of published sources including the Tobacco Control Database of the World Health Organization Regional Office for Europe. ${ }^{9}$

The development of a quantitative model to explain the relation between FDI and tobacco control was considered. However, given the limited data (FDI data are available for only eight countries) and the fact that many of the variables that we wished to include, such as degree of democratisation, do not lend themselves to precise quantification, we felt any attempts to do so would introduce a degree of precision that, while superficially convincing, could not be justified.

\section{RESULTS}

\section{Tobacco industry investments}

Russia and Ukraine, the two most populous states, received the greatest investment with all the major TTCs staking a claim (tables 1 and 2) (to view tables $1-5,7,8$ go to http// www.tobaccocontrol.com/supplemental). Reports suggest that foreign owned factories now account for between $60 \%{ }^{10}$ and $90 \%$ of the tobacco market. ${ }^{11-13}$

The three small Baltic states have each received investments from single companies (table 3). The Danish company, House of Prince (in which British American Tobacco (BAT) has a significant stake) invested in Latvia ${ }^{14}$ and Swedish Match (then Svenska Tobaks) in Estonia, ${ }^{15}$ each purchasing the country's only tobacco factory. Philip Morris bought one of Lithuania's two main factories, and then constructed a second plant, forcing the government owned plant in Kaunas to close. This has left Philip Morris, Lithuania's third largest single investor, ${ }^{16}$ as the sole manufacturer ${ }^{17}$ with a market share of some $85 \%{ }^{18}$

TTCs have also invested in three of the five central Asian republics (table 4) securing monopoly positions in two, Kyrgyzstan and Uzbekistan. By 1999, BAT had achieved a market share of over $70 \%$ in Uzbekistan, ${ }^{10}{ }^{19}$ and as the country's largest foreign investor, ${ }^{20}{ }^{21}$ has been able to secure favourable treatment from the government, including a five year extension of its preferential tax-exempt status. ${ }^{22}$ While Philip Morris does not have a manufacturing monopoly in Kazakhstan, it has a market share of over $70 \%{ }^{10}$ and is the country's largest taxpayer. ${ }^{23}$

Conflict and political instability initially delayed investment in the Caucasus, a major leaf producing region in Soviet times. However, between 1997 and 2000, two joint ventures were established in Armenia ${ }^{24-26}$ (table 5), the first with Grand Tobacco of Canada, now reputed to be the country's second largest taxpayer ${ }^{27}$ controlling between $50 \%{ }^{24}$ and $70 \%{ }^{28}$ of the market. Azerbaijan saw failed investments by RJ Reynold's (now part of Japan Tobacco International) and others, ${ }^{29}{ }^{30}$ but in 1999 Athens based European Tobacco Inc, with support from Altadis, acquired the Baku factory ${ }^{10}{ }^{31}$ for an estimated $\$ 50$ million. $^{32}$

By the end of 2000 the five remaining countries in the region had yet to see any direct foreign investment in tobacco. The Georgian tobacco industry was privatised in 1998 and although the TTCs did not invest directly, in 2001 BAT spent a reported US\$15 million establishing a licensed production operation in Georgia ( $G$ Bakhhturidze, personal communication 2002). In Belarus the arch conservative President Lukaschenko has resisted privatising the economy, thwarting BAT's and RJ Reynold's concerted attempts to establish a joint venture. ${ }^{33}$ Turkmenistan has no cigarette manufacturing facility and the highly autocratic President Niyazov, since being advised to give up smoking after major heart surgery, has decreed smoking a vice and banned it in public. ${ }^{34}$ While Moldova, at least until the recent election of the Communist Party, had taken a more liberal attitude to market reform, privatisation of its tobacco industry has proved contentious. Despite pressure from the International Monetary Fund (IMF) and purchasing attempts by Reemtsma and BAT, the tobacco industry remains in state hands. ${ }^{35-38}$ In Tajikistan, the five year civil war following independence, three changes in government, and widespread violence have discouraged investment. ${ }^{39}$

\section{Contribution to FDI}

By the end of 2000 the TTCs had invested at least US\$2.7 billion in 10 countries of the FSU (table 6), US\$1.7 billion of this in Russia. The TTCs' contribution to FDI has been most significant in Uzbekistan where BAT's investment accounts for one third of total FDI. Although the price Reemtsma paid in Kyrgyzstan is unknown, it is identified as one of the country's major investors and its contribution to FDI is therefore likely to be significant. ${ }^{40}$ In Russia, Ukraine and Kazakhstan tobacco money accounts for over $4 \%$ of FDI, while in the Baltics and Caucasus it has played a less important role. Data for Latvia and Lithuania show that despite Philip Morris being the third largest investor in Lithuania, due to the considerable investments made in other sectors including telecoms and electronics, tobacco investments account for only $1-3 \%$ of FDI. Although data are not available for Estonia, the EBRD has not recognised tobacco as a major sector for investment. ${ }^{41}$

Tobacco FDI per capita shows a broadly similar pattern with lower rates in the Caucasus and Baltics and higher rates elsewhere, although Lithuania and Ukraine are exceptions to this pattern.

\section{Consequences of TTC investments}

\section{Production capacity and market share}

Production capacity has increased 10-fold in Kyrgyzstan, sixfold in Uzbekistan, over fourfold in Russia, tripled in Lithuania, and doubled in Kazakhstan (tables 1-4). In Ukraine, Estonia, and Latvia increases in capacity have been more modest although actual production has increased by at least $50 \%$.

Based on legally traded cigarettes, TTC market share has increased from zero pre-1990 to reach levels of $50-100 \%$ in markets in which they have invested (table 7). However, levels of smuggling remain substantial, particularly in countries where the TTCs have yet to invest directly, ${ }^{10}$ and the TTCs' market share is therefore likely to be larger in these markets than official data suggest.

\section{Introduction of branding and advertising}

In the Soviet era, the western concept of branding was virtually unknown. Almost all cigarette brands were state owned and each factory produced a variety of brands (the exception was the Yava brand, produced exclusively by the Yava factory later acquired by BAT). Most were traditional filterless cigarettes (papirossi or oval cigarettes) with a few low priced filter brands. ${ }^{42}$ Since the mid 1990s the TTCs have gained ownership of existing brands, developed new brands specifically for these markets and introduced their own international brands. JTI, for example, introduced eight new brands in 1999 alone. $^{43}$ The TTCs have also focused production on filter brands, the consumption of which increased through the 1990s, although this trend reversed temporarily after the 1998 financial crisis. ${ }^{13} 44$ 


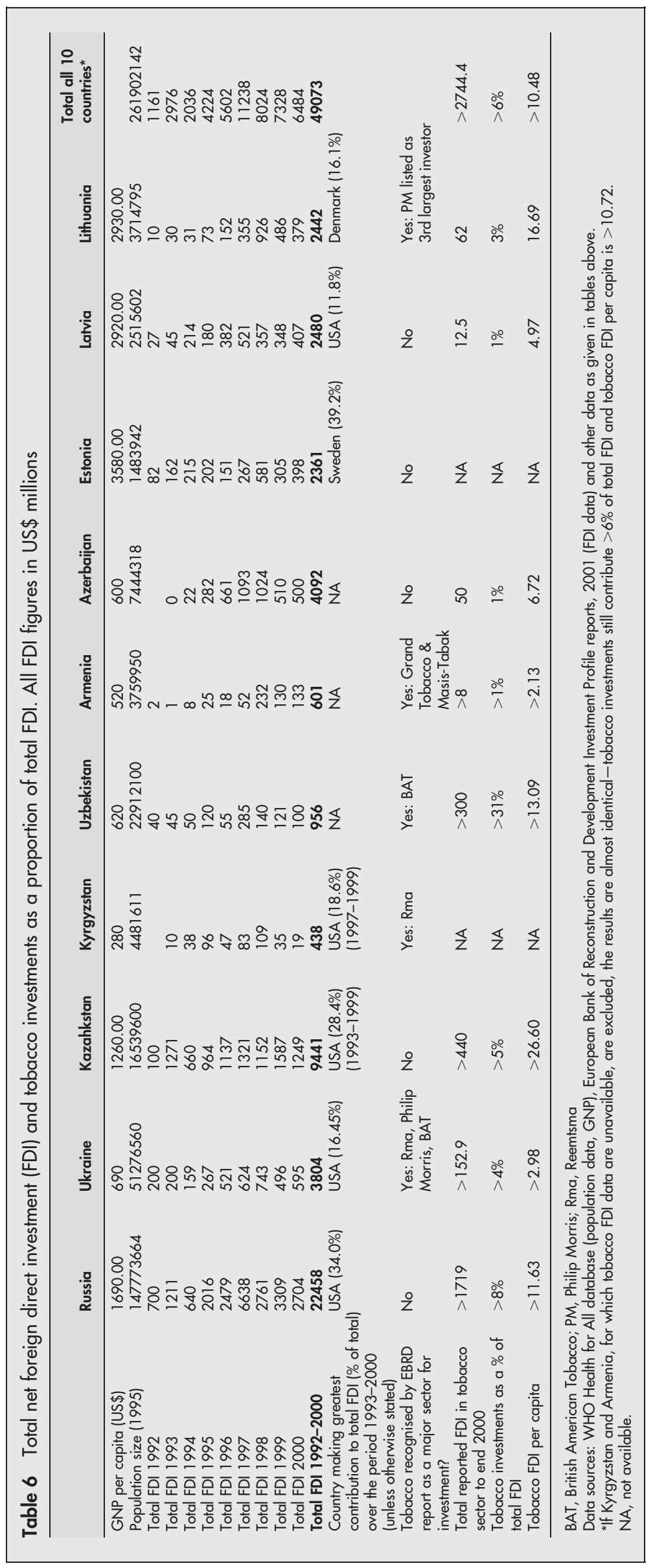

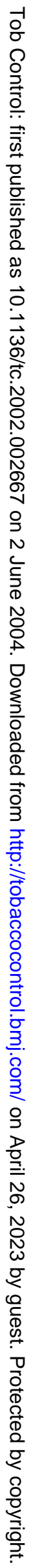


The Soviet Union had a wide range of anti-smoking policies. Although advertising was unnecessary and nonexistent, tobacco advertising was banned, smoking was forbidden in many public places including subways, buses and restaurants, cigarette packages carried health warnings, and anti-smoking campaigns were televised. ${ }^{45}{ }^{46}$ Post-transition the TTCs exploited confusion over the legality of this Soviet legislation by advertising heavily to establish their brands, ${ }^{47}$ leading to a major surge in advertising and promotion. ${ }^{48}$ By the mid 1990s it was estimated that up to $50 \%$ of all billboards in Moscow and $75 \%$ of plastic bags in Russia carried tobacco advertising. ${ }^{49}$ In at least four of the former Soviet states the tobacco transnationals soon ranked among the top 3 advertisers, ${ }^{50}$ and in some states where data are available, still do so, particularly in advertising categories that remain unrestricted. ${ }^{52} 53$

\section{Tobacco control}

Tobacco control policies have been enacted to varying degrees in each country (table 8). Initial attempts to implement effective tobacco control policies were fraught with difficulties. In Russia, the absence of enforcement mechanisms rendered the 1993 tobacco advertising ban ineffective. ${ }^{54}$ In 1995 a further law was passed, but based on the industry's voluntary code of conduct ${ }^{55}$ only included minor restrictions on content, placement of outdoor adverts, and timing of broadcast adverts.56 In July 2001 a new federal bill on Limitation of Tobacco Consumption was signed to be introduced in stages from 2002. The original bill included highly effective measures but, as the St Petersburg Times notes, the changes made to the draft between the first and second readings were "a textbook demonstration of the lobbyist's art" ${ }^{57}$ The initial tobacco advertising ban was excluded when the industry successfully argued that it should be subject to a separate law. Similarly the original ban on showing smoking in movies has been weakened to allow smoking if it is "an integral element of the artistic design" ${ }^{.57}$ Some restrictions on smoking in public are set but no clear system of enforcement is specified. While a few of the remaining components of the bill remain useful, in particular a ban on sales from vending machines, of packs of under 20 and single cigarettes, it is clear that industry interests triumphed. ${ }^{58}$

Similar problems have been encountered elsewhere. In Ukraine a 1994 decree failed to define "advertising" and was therefore easily contravened. In 1996 the Rada gave preliminary approval to a law that was essentially a translation of the voluntary code submitted by the industry but, following protests from the tobacco control lobby, ultimately enacted a stronger ban. ${ }^{59}$ The industry lobby responded with a report from the so-called "Association of Independent Advisors", for which Philip Morris later admitted responsibility, arguing that Ukraine would lose US $\$ 400$ million as a result of an advertising ban..$^{59}$ This led to a presidential veto of the ban and finally, in July, the Rada introduced a much weakened ban that covered only television, radio, and cinema advertising. As in Russia, there are many loopholes and enforcement is weak. Ukraine, however, has a more active tobacco control lobby than many other FSU countries, and a recently established coalition of anti-smoking organisations has made some progress in promoting more effective tobacco control policies.

The central Asian states Kazakhstan, Kyrgyzstan, Tajikistan, and Uzbekistan have few measures to reduce tobacco use; in contrast in Turkmenistan progress has been made because of the strong position taken by the president. ${ }^{60}$ The picture in the Caucasus varies widely with excellent tobacco control policies in place in Azerbaijan, but weak policies in Armenia and Georgia where implementation of an advertising ban approved in 1998 was delayed by industry lobbying.

Progress in Moldova and the three Baltic states has been better. Lithuania has a strong public health lobby, partly as a result of individuals participating in international research projects even during the Soviet era. ${ }^{61}$ It was one of the first east European countries to develop comprehensive tobacco control legislation ${ }^{62}$ and has been described by industry journals as "the most virulently anti-smoking in the Baltic States". ${ }^{63}$ Nevertheless, its advertising ban, which covered both direct and indirect advertising, and was due to come into force in July 1996, was not implemented until May 2000 because of a series of challenges. Estonia enacted its first advertising ban in 1993 but the industry exploited loopholes in the law, requiring a further act which covers direct advertising (other than cable TV and international print media) but which does little to restrict indirect advertising. The second act came into effect in 1998 and a subsequent Tobacco Act, banning smoking in public places and smokeless tobacco, was adopted in June 2000. Latvian attempts to pass an advertising ban in 1996 failed because of intense opposition. A subsequent ban has outlawed television, radio, and outdoor advertising but does not restrict point of sale, cinema, or indirect advertising and only partially restricts adverts in the printed media.

Industry journals do not hide the fact that the tobacco companies were angered by the tobacco control measures taken in these three countries, in particular the substantial excise tax increases (the three Baltic states have considerably higher excise rates than most other FSU countries) $)^{64}$ and the governments' refusal to maintain import duties to protect investing companies. ${ }^{18} 65$ The latter seems somewhat ironic given the industry's frequent lobbying for reductions in trade barriers where such changes suit their interests. The industry claims that the Baltic governments have contravened promises they made of favourable taxation rates and, as frequently argued elsewhere, that price increases have led to an influx of cheap smuggled cigarettes that make it impossible for them to compete. ${ }^{65} 66$

\section{Prevalence}

These changes appear to have had an impact on smoking habits. The transfer to filter brands, and light brands which are easier to smoke particularly for new smokers, is thought to increase the number of cigarettes smoked per day and, in line with the increase in targeted advertising, to influence the decision of women to smoke. ${ }^{23}$ This appears to have happened in the FSU where trends in smoking prevalence can most accurately be assessed for Russia, Ukraine, and the three Baltic states and even then only over the last 10-15 years. ${ }^{67}$ Most data suggest rates in men have been reasonably steady through the 1990s, although longer term trends in Russia suggest that current rates are higher than those recorded in the 1980s. ${ }^{67}$ Rates in women, however, appear to have increased and are now particularly high among women in cities ${ }^{67-70}$ Repeat youth surveys (1993-94 and 1997-98 $)^{71}{ }^{72}$ in the Baltics and Russia (St Petersburg) and comparison of surveys in Moscow between $1985^{73}$ and $1995^{74}$ suggest youth smoking has also been increasing, particularly in girls.

\section{DISCUSSION}

While the data provided in this paper are as comprehensive as possible, a number of potential weaknesses must be considered. Firstly, data on FDI are notoriously difficult to collect. In some instances we were unable to obtain data on tobacco industry investments and in other instances only minimum investment figures were available. Tobacco industry investment will therefore be underestimated. However, 
because of the high levels of total FDI compared to levels of tobacco industry investment, relatively large increases in industry investments would have only a small impact on the calculated percentage contribution to FDI. Thus, for example, anecdotal reports suggest that Philip Morris invested \$60 million and the TTCs together a total of approximately $\$ 200$ million in Ukraine. ${ }^{75}{ }^{76}$ This would, however, only increase the tobacco industry's contribution to FDI from our estimate of over $4 \%$ to $5.3 \%$. Despite these weaknesses, the data provide the most comprehensive assessment yet of industry investments in the FSU.

We estimate that production capacity in the countries receiving investments has almost tripled. Actual output may have increased by a greater amount as many factories operated well below capacity in the pre-transition period and post-investment capacity is unknown in some instances. For example, we were unable to identify new capacity levels in Latvia, but US Department of Agriculture data suggest production increased from approximately 2.6 to 6.4 billion cigarettes between $1993^{77}$ and $2000 .^{78}$

Transition clearly heralded changes to the region's tobacco industry that will have major implications for future health. The TTCs established new cigarette brands, exerted ownership over existing brands, expanded marketing, and used their powerful lobby to undermine the development of effective tobacco control. The argument that foreign investment simply led to a substitution of traditional tobacco products with new ones can therefore be comprehensively rejected. Moreover, despite difficult trading conditions and the 1998 economic crash, the TTCs already report good returns on their investments. ${ }^{79-84}$

The findings have led us to conclude that, in the 15 countries of the FSU, five distinct patterns can be ascertained, corresponding to the size of the country, the nature of the political and economic transition, and the emerging political situation in each. The latter varies along a spectrum from parliamentary democracy at one end, best exemplified by the Baltic States, to personal dictatorships at the other with Belarus and Turkmenistan the best examples. ${ }^{85}$ These factors were important both in influencing initial TTC interest and investments and determining their degree of influence once investment had occurred.

First, Russia and Ukraine attracted substantial inward investment in many sectors, reflecting the extensive privatisation of the existing broadly based industrial infrastructure. The TTCs competed for market share in what were the FSU's largest potential markets, with none achieving dominance. The strength of the industry, coupled with the lack of nongovernmental organisations and low awareness of the health consequences in weak legislatures, meant that effective action was undermined or delayed. However, a strengthening civil society and fledgling tobacco control lobby is now emerging with some progress seen in tobacco control.

The second model, seen in the Baltic States, is characterised by some inward investment but only moderate political influence by the industry which, to some extent, has been countered by the tobacco control community. The small population sizes make these markets less important to the industry and tobacco is a much smaller part of the overall economy. Thus the scope and incentive for industry influence is smaller. But perhaps more important is the development of open, pluralistic political systems, with lower levels of corruption and better developed civil society. Their planned accession to the European Union has also been a factor, although this has been used by both industry and tobacco control advocates, with Estonia enacting legislation based on EU policies but tobacco lobbyists in Lithuania citing the annulment of the EU advertising ban as a reason to weaken and delay advertising legislation.
The third model is seen in Uzbekistan, Kyrgyzstan, and Kazakhstan, countries with autocratic governments that have seen large industry investments and the establishment of monopoly (Uzbekistan and Kyrgyzstan) or near monopoly positions (Kazakhstan) despite Uzbekistan and Kazakhstan being, respectively, the third and fourth most populous postSoviet states. The TTCs' major contribution to FDI gives them considerable political and economic power, power that appears to be easily wielded in these highly centralised, one party states. Moreover, given that dissent and free speech are poorly tolerated, tobacco control groups are virtually unknown and tobacco control policies are among the weakest in the region. ${ }^{86}$

A fourth group of countries has avoided tobacco investments, at least until recently, and tobacco control has made measured progress most notably in Moldova, the most democratic of the four, and Azerbaijan. The lack of investment reflects resistance to economic reform in general (Belarus and Turkmenistan), more specifically to privatisation of key sectors deemed to be of national importance (Moldova), or to chaotic post-transition conditions that discouraged and undermined attempted investment (Azerbaijan). The Turkmen president occupies a position of almost unparalleled power in his country ${ }^{87}$ and tobacco control progress there can be attributed his personal animosity towards tobacco. Belarus is still considered an important market by the TTCs, who hope that integration with Russia will occur. ${ }^{88}$ As a result, BAT and Philip Morris are among the largest advertisers in Belarus ${ }^{52}$ despite their small official market share ${ }^{10}$ and progress on tobacco control has therefore been limited. Some sectors of the Azerbaijani economy have opened up to enable exploitation of its substantial oil reserves and although Azerbaijan recently received inward tobacco industry investment, it had previously enacted tough anti-smoking policies, at least on paper.

Finally, there is a group of countries affected either by war or almost complete economic collapse, in which there are few functioning institutions and very limited governmental capacity (the Caucasus and Tajikistan). Despite obvious difficulties, smaller international tobacco companies have recently invested in Armenia. The industry seems to regard Tajikistan as too difficult to invest in and perhaps better served by exports from elsewhere. A similar situation exists in Albania. These countries have weak tobacco control policies, which seems to reflect the lack of governmental capacity rather than TTC influence.

While there are many similarities with TTC entry into Asia, some underlying features are different. Firstly, liberalisation of inward investment has ultimately been more important than trade liberalisation. Secondly, market entry coincided with huge political and economic upheavals, with legislative activity focused on basic state building, and the need to develop a constitution and implement economic reform. There were no effective tobacco control policies in place to act as a buffer against the industry and the development of new legislation was understandably given a low priority amid other pressing demands. The entry of the TTCs, with their millions of investment dollars, was a further disincentive to effective tobacco control. Moreover, civil society was not well developed and proponents of tobacco control had little voice. As the industry journal World Tobacco for Russia and Eastern Europe stated with delight: "anti-tobacco activists are almost unknown in Russia so the Russian people and government have not been bombarded with anti-tobacco propaganda." ${ }^{\prime 49}$ As a result, TTCs met little if any resistance, unlike their experience in some Asian countries. Indeed investments were often encouraged, not only by governments but also by international financial organisations such as the IMF. ${ }^{37} 89$ 


\section{What this paper adds}

Previous studies suggest that entry of the tobacco transnational companies (TTS) to countries with state run tobacco industries can have a major impact on tobacco control. Most evidence comes from the TTCs' entry to Asia, but little is yet known about their entry to the former Soviet Union (FSU) or its impact.

This study shows that TTC entry to the FSU differed to that in Asia in a number of respects. Liberalisation of inward investment was more important than trade liberalisation. Competition increased only in the most populous states; elsewhere state monopolies were replaced with transnational monopolies. Certain features of market entry made many FSU countries particularly vulnerable to industry influence: its concurrence with major political and economic change, pressure from international financial organisations for industry privatisation, the TTC's major contribution to foreign direct investment, their ability to take over existing monopolies, and the centralised, corruptible political systems that existed in some countries.

Thirdly, the ability to take over existing monopolies in all but the largest countries contrasts with the competitive positioning seen in Asian markets. Together with their major contribution to FDI, this has given the tobacco companies a unique degree of political influence. In well functioning democracies, such influence may be effectively counteracted, as illustrated by the Baltic states. But elsewhere in the FSU, particularly the central Asian republics, industry and government collusion has left the industry in an extremely powerful position.

This initial analysis suggests that further work is needed to examine in more detail the influence of the tobacco industry over specific policies and the impact these investments have had on patterns of tobacco consumption.

\section{ACKNOWLEDGEMENTS}

The authors would like to thank George Bakhturidze, Janis Caunitis, Andrey Demin, George Gotsadze, Konstantin Krasovsky, Andrus Lipand, Tomas Stanikas, Irina Zatusevski and others for their assistance. The views expressed in this paper are those of the authors. This work was supported in part by the National Cancer Institute, US National Institutes of Health, grant number R01 CA91021.

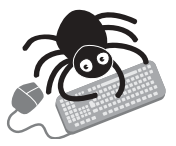

To view tables 1-5, 7, 8 visit the Tobacco Control website-http//www.tobaccocontrol.com/ supplemental

\section{Authors' affiliations}

A B Gilmore, M McKee, European Centre on Health of Societies in Transition, London School of Hygiene and Tropical Medicine, London, UK

\section{REFERENCES}

Rupert J, Frankel G. In ex-Soviet markets, US brands took on role of capitalist liberator. Washington Post 19 November 1996.

2 Mackay J. US tobacco export to Third World: Third World War. J Natl Cancer Inst 1992;(monographs):25-8.

3 Connolly GN. Worldwide expansion of the transnational tobacco industry. J Natl Cancer Inst 1992;(monographs):29-35.

4 Chaloupka FJ, Laixuthai A. US trade policy and cigarette smoking in Asia. National Bureau of Economic Research Working Paper No. 5543, 1996.

5 Bettcher D, Subramaniam C, Guindon E, et al. Confronting the tobacco epidemic in an era of trade liberalisation. Geneva: World Health Organization, TFI, 2001.
6 Taylor A, Chaloupka FJ, Guindon E, et al. The impact of trade liberalisation on tobacco consumption. In: Jha P, Chaloupka F, eds. Tobacco control in developing countries. Oxford: Oxford University Press, 2000.

7 Connolly GN. Tobacco, trade and eastern Europe. In: Slama K, ed. Tobacco and health. New York: Plenum Press, 1995.

8 United Nations Conference on Trade and Development (UNCTAD). World Investment Report 2001, Promoting Linkages. Geneva: United Nations, 2001.

9 Anon. http://cisid.who.dk/tobacco/ (last accessed 12 May 2003).

10 ERC Statistics International plc. The World Cigarettes I and II: The 2001 survey. Suffolk, Great Britain, 2001.

11 Volodina W, Alexeyev I. Meeting more than the market's demand. Tobacco Journal International 2001;3:27-35.

12 Volodina S. Ukraine: Mastering the crisis. Tobacco Journal International 2000;4:64-70.

13 Anon. Filter cigarettes make headway on Ukraine's turbulent market. World Tobacco for Russia and Eastern Europe 2000;1:3-7.

14 Anon. Tobacco traveller: Latvia. Tobacco Journal International 1994;3:66.

15 Anon. Tobacco traveller: Estonia. Tobacco Journal International 1994;3:64.

16 European Bank of Reconstruction and Development. Lithuania investment profile 2001

17 Anon. Kova plant closed. Tobacco Journal International 1996:4:58

18 Glogan T. King Philip of Lithuania. Tobacco Journal International 2000; 1:40.

19 European Bank of Reconstruction and Development. Uzbekistan: investment profile 2001.

20 Tuinstra T. Following the Silk Route. Tobacco Reporter 1998; October: 143-5.

21 Anon. Tobacco traveller: Uzbekistan. Tobacco Journal International 1996;4:63.

22 United States Department of Agriculture, Foreign Agricultural Section. Uzbekistan, Republic of: Tobacco and Products Annual 2000. Gain Report \#UZO005. April 2000. (www.fas.usda.gov/gainfiles/200004/ 25667473.pdf).

23 Khan MA. New tobacco factory opened in Kazakhstan. Tobacco Journal International 2000;4:71-2.

24 Anon. Armenia: Canadian involvement. Tobacco Journal Internationa 1997;4:4

25 Anon. http://www.export.am/Guides/Country_Prof/MainSect/ FoodProc.htm (last accessed 27/2/02)

26 European Bank of Reconstruction and Development. Armenia: Investment Profile 2001

27 http://www.agbu.org/pages/canada/canarmbus.html (last accessed 27 February 2002)

28 Wright R. Cigarettes help build impoverished Armenia. The Russia Journal April 6-12, 2001. http://www.Russiajournal.com/weekly/pdfs/ 106_16.pdf (last accessed 4 April 2002)

29 Anon. Azerbaijan: RJR in Joint venture. Tobacco Journal International 1996:4:4

30 United States Department of Agriculture, Foreign Agricultural Section Azerbaijan, Republic of: Tobacco and Products Annual Report 2000. GAIN Report \#AJ0002.June 2000. (http://www.fas.usda.gov/gainfiles/ 200003/25637244.pdf).

31 Reuters. Investors reopen Azerbaijan's sole tobacco plant. 3 February 2000. http://lists.essential.org/pipermail/intl-tobacco/2000q 1/000038.html (last accessed 1 June 2003)

32 European Tobacco-Baku now country's biggest taxpayer. http:// www.internationalspecialreports.com/ciscentralasia/01/azerbaijan/ europeantobacco.html (last accessed 3 June 2003).

33 Anon. Tobacco Traveller: Belorussia. Tobacco Journal International 1996;4:61.

34 Hidalgo L. Turkmen face smoking ban. BBC News. (http://news.bbc.co.uk/ hi/english/world/asia-pacific/newsid_602000/602581.stm).

35 Anon. Moldova: New bids considered. Tobacco Journal International 1997;2:6

36 Weissman R, White A. Needless harm, International Monetary fund support for tobacco privatization and for tobacco tax and tariff reduction and the cost to public health. Washington DC: Essential Action, 2002.

37 European Bank of Reconstruction and Development. Moldova: Investment profile 2001

38 Anon. Moldova Joint Venture. Tobacco Journal International 1996:5:7.

39 Anon. Tobacco Traveller: Taiikistan. Tobacco Journal International 1996;6:82

40 European Bank of Reconstruction and Development. Kyrgyzstan: investment profile 2001.

41 European Bank of Reconstruction and Development. Estonia: investment profile 2001

42 Dimitrov V. Russian factories need 150 new lines. World Tobacco for Russia and Eastern Europe 1997;II:3-18.

43 Mitreva M. Russia's revival. Tobacco Reporter 2000;July:48-51.

44 Crescenti MG. Russia Getting back on its feet. Tobacco Journal International 1999;6:54-6.

45 Cooper R. Smoking in the Soviet Union. BMJ 1982;285:549-51

46 Zaridze D, Dvoirin VV, Kobliakov VA, et al. Smoking patterns in the USSR In: Zaridze DG, Peto R, eds. Tobacco: a major international health hazard, IARC Scientific publications No. 74. Lyon: IARC, 1986.

47 Prokhorov A. Getting on Smokin' Route 66: tobacco promotion via Russian mass media. Tobacco Control 1997;6:145-6.

48 Hurt RD. Smoking in Russia: what do Stalin and western tobacco companies have in common? Mayo Clin Proc 1995;70:1007-11

49 Dragounski D. Well - this is the Russian market. World Tobacco for Russia and Eastern Europe 1998;Il:32-46. 
50 Anon. http://www.corporateinformation.com/uasector/Advertising.html (last accessed 2 January 2001).

51 Anon. http://www.adageglobal.com/cgi-bin/pages.pl?link= 445 (last accessed 5 April 2002).

52 Zenith Media. Central and Eastern Europe market and mediafact. London: Zenith Optimedia, 2000.

53 Zenith Media. Central and Eastern Europe market and mediafact. London: Zenith Optimedia, 2003.

54 McKee M, Bobak M, Rose $R$, et al. Patterns of smoking in Russia. Tobacco Control 1998;7:22-26.

55 Partsch C. New law bans TV ads for cigarettes, alcohol. St Petersburg Times, 27 June-3 July 1995. (http://www.sptimesrussia.com/secur1/112/newlaw.html) (last accessed 29 January 2001).

56 World Tobacco File 1997. London: Market Tracking International Limited, 1999.

57 Kutuzov R. Rybak S, Neimysheva N. Duma dilutes anti-tobacco law. St Petersburg Times 19 June 2001. (http://www.sptimesrussia.com/secur/ 679/news/b_3717.htm?725curr) (last accessed 29 November 2001).

58 United States Department of Agriculture, Foreign Agricultural Service. Import requirements and restrictions for tobacco products in foreign markets. Supplement to Tobacco: world markets and trade, July 1999 (Available on http://www.fas.usda.gov/tobacco/circular/1998/impreqmts/ imprqmts.htm).

59 Krasovsky K. Abusive international marketing and promotion tactics by Philip Morris and RJR Nabisco in Ukraine. In: INFACT, Global aggression, the case for world standards and bold US action challenging Phillip Morris an RJR Nabisco. New York: Apex Press, 1998.

60 WHO Regional Office for Europe. The European Report on Tobacco Control Policy. Review of implementation of the Third Action Plan for a Tobacco-free Europe 1997-2001. Copenhagen: World Health Organization, 2002.

61 Pudule I, Grinberga D, Kadziauskiene K, et al. Patterns of smoking in the Baltic Republics. J Epidemiol Comm Health 1999;53:277-83.

62 Stanikas T. Tobacco control in Lithuania. Undated. (http:// health21.hungrary.globalink.org/filternonline/exvclusive/lithuania.html) (last accessed 12 November 2001).

63 Anon. Lithuania health warnings. Tobacco Journal International 1996;5:7.

64 World Bank. Economics of tobacco for the Europe and Central Asia (ECA) Region, May 2001. http://wwwl.worldbank.org/tobacco/pdf/ country\%20briefs/Eastern\%20and\%20Central\%20Asia.pdf (last accessed 11 June 2002).

65 Glogan T. Contraband impairs Estonian market. Tobacco Journal International 1999:5:69.

66 Glogan T. Latvia suffers under barrage of contraband. Tobacco Journal International 1999;6:95-6.

67 Forey B, Hamling J, Lee P, et al. International smoking statistics, 2nd ed. Oxford: Oxford University Press, 2002

68 Gilmore A, McKee M, Telishevska M, et al. Smoking in Ukraine: epidemiology and determinants. Prev Med 2001;33:453-61.

69 Pomerleau J, Gilmore A, McKee M, et al. Determinants of smoking in eight countries of the former Soviet Union: results from the Living Conditions, Lifestyles and Health Study. (in press).

70 Gilmore A, McKee M, Rose R. Smoking in Belarus: evidence from a household survey. Eur J Epidemiol 2001;17:245-53.

71 King A, Wold B, Tudor-Smith C, et al. The health of youth: a cross-national survey. WHO Regional Publications, European Series No. 69, 1996. http:// www.hbsc.org/downloads/HealthofYouth 1.pdf (last accessed 1 June 2003).

72 Currie C, Hurrelmann K, Settertobulte W, et al, eds. Health and health behaviour among young people. WHO policy series: health policy for children and adolescents issue 1. International report. Copenhagen: World Health Organization, 2000. http://www.hbsc.org/downloads/ Int Report_00.pdf (last accessed 1 June 2003).

73 Prokhorov AV, Alexandrov AA. Tobacco smoking in Moscow school students. Br J Addict 1992;87:1469-76.

74 Alexandrov AA, Alexandrova V, Ivanova El. Prevalence of smoking among Moscow school children and approaches to prevention. In: Lu R, Mackay J Niu S, Peto R, eds. Tobacco: the growing epidemic. Proceedings of the Tenth World Conference on Tobacco or Health, 24-28 August 1997, Beijing, China. London: Springer-Verlag, 266-8.

75 Talov I. Portraits of producers. Business, 26 February 2001 [Russian]. http:// www.business.ua/i424/a8273/ (last accessed 9 July 2003).

76 Talov I. Industrial trade survey of the tobacco industry. Business, 26 February 2001 [Russian]. www.business.ua/i424/a8272 (last accessed 9 July 2003).

77 Anon. Statistics: production of cigarettes. Tobacco Journal International 1997:6:87-90.

78 United States Department of Agriculture, Foreign Agricultural Service. World Tobacco Markets Circular series FT-3-01 September 2001.

79 British American Tobacco. Quarterly Report to 30 September 1998. London: British American Tobacco, 1998.

80 British American Tobacco. Quarterly Report to 31 March 1999. London: British American Tobacco, 1999
81 British American Tobacco. Quarterly Report to 30 September 2000. London: British American Tobacco, 2000

82 British American Tobacco. Quarterly Report to 31 March 2001. London: British American Tobacco, 2001

83 Philip Morris. Excerpts from the Philip Morris Companies Inc. 2000 Fact Book. (http://www.pmint.com/fin_overview/book.html) (last accessed 6 November 2001).

84 Edgecliffe-Johnson A. Discounting fails to dent Philip Morris. Financial Times 18 October 2001:31.

85 Parrott B. Perspectives on postcommunist democratisation. In: Dawisha K, Parrott B, eds. Conflict, cleavage and change in Central Asia and the Caucasus. Cambridge: Cambridge University Press, 1997.

86 Uzbekistan: who's in charge now? Tobacco Control 2000;9:359-6.

87 Anon. Health and dictatorship: effects of repression in Turkmenistan. Lancet 2003;361:69-70.

88 Anon. A tactical market. Interview with Denis Gourinovich, corporate relations manager at BAT in Belarus. Tobacco Journal International 12 February 2003. http://www.tobaccojournal.com/ show_artikel.php3?id=2971 (last accessed 6 June 2003).

89 Chossudovsky M. The "Thirdworldisation" of the Russian Federation. In: The globalisation of poverty, impacts of IMF and World Bank Reforms. London: Zed books, 1998.

90 Horne B. Russia strives to create more attractive climate for foreign investment. Tobacco Journal International 1995;6:12-18

91 Anon. Tobacco Traveller: Russia update. Tobacco Journal International 2000;6:82-5.

92 Crescenti MG. A market for the brave. Tobacco Journal International 1997;6:14-21.

93 Callard C. Collishaw N, Swenarchuk M. An introduction to international trade agreements and their impact on public health measures to reduce tobacco use. Ottawa: Physicians for a Smoke-Free Canada, April 2001.

94 Tuinstra T. Light in the darkness. Tobacco Reporter 1999;August:32-34.

95 Anon. Russia, BAT investment. Tobacco Journal International 1997;4:98.

96 Anon. 1998 revisited. Tobacco Journal International 1999; Yearbook:4-8.

97 Anon. Rothmans' new plant. Tobacco Journal International 1997;6:8.

98 Volodina S. Showtime for tobacco. Tobacco Journal International 2000;5:90-2.

99 Anon. 1999 revisited. Tobacco Journal International 2000;Yearbook:6.

100 Anon. Major investments indicate continuing faith in local production. World Tobacco for Russia and Eastern Europe 1998;1I:39-40.

101 Crescenti MG. Confidence in a Turbulent market. Tobacco Journal International 2000;1:26-7.

102 Hundley L. Investing. Tobacco Reporter 1995;September:60-62.

103 Anon. Major investments indicate continuing faith in local production. World Tobacco for Russia and Eastern Europe 1998;II:39-40.

104 Anon. Four multinationals, J Reynolds, Philip Morris, BAT and Reemtsma have purchased stakes in Ukrainian factories. Tobacco Reporter 1996; July:45-48.

105 Anon. Foreign involvement in the tobacco industries of Eastern Europe and the Former Soviet Union. (status August 1994). Tobacco Journal International 1994;5:97-104 (insert).

106 Anon. Four multinationals, RJ Reynolds, Philip Moris, BAT and Reemtsma, have purchased stakes in Ukrainian factories. Tobacco Reporter 1996;July:45-8.

107 Anon. Tobacco Journal International 1996;5:7

108 Phillip Morris International. (http://www.pmintl.com/about_us/ history.html) (last accessed 7 March 2001).

109 Anon. 1996 revisited (Ukraine). Tobacco Journal International 1997; Yearbook:8

110 Horne B. Opposition to reform hinders economic growth in Ukraine. Tobacco Journal International 1995;6:20-2.

111 TR Staff. Multinational investment. Cigarette company acquisitions in Central and Eastern Europe. Tobacco Reporter 1998; Winter (bonus issue):36-7

112 Shchur V. Foreign investment igniting tobacco market. Kyiv Post 23 May 2002 (http://www.kpnews.com/displaypr.php?arid = 11122) (last accessed 12 September 2002).

113 Anon. Late News: Lithuania new factory. Tobacco Journal International 1994;5:112.

114 Glogan T. Baltic Tobacco industries struggle to develop. Tobacco Journal International 1995:4:54-8.

115 Anon. Tobacco Traveller: Kazakhstan. Tobacco Journal International 1996;6:81.

116 Khan MA. New tobacco factory opened in Kazakhstan. Tobacco Journal International 2000:4:71-2.

117 Horne B. Involvement in Eastern Europe and the FSU. Tobacco Journal International 1994;5:88-96.

118 Horne B. BAT forging ahead with factory in Samarkand. Tobacco Journal International 1997:1:20-2

119 Anon Kyrygzstan. Tobacco Journal International 2001;Yearbook:8. 